\title{
PENGARUH PEMANASAN BAHAN BAKAR MELALUI PIPA BERSIRIP TRANSVERSAL PADA UPPER TANK RADIATOR DAN PENAMBAHAN ETANOL TERHADAP EMISI GAS BUANG PADA TOYOTA KIJANG
}

\author{
Danar Susilo Wijayanto, Ngatou Rohman, Ranto, Husin Bugis, Ahmad Yuhsin Sukisno, dan \\ Muhammad Rodhi Qoribi \\ Prodi Pendidikan Teknik Mesin, Jurusan Pendidikan Teknik dan Kejuruan, FKIP, UNS \\ Kampus UNS Pabelan, Jl. Ahmad Yani 200, Surakarta, Tlp/Fax (0271) 718419/ 716266 \\ Email :danarsw@yahoo.com
}

\begin{abstract}
The purpose of this study were to determine the effect usage of gasoline heating through a capillary tube which is transversal finned in the upper tank of radiator on exhaust emissions of CO and HC in the engine of Toyota Kijang. This study is experimental. The sample in this study was the machine of Toyota Kijang. Free variable of the research is the usage of fuel heating with fin variations on the copper capillar tube consist of copper capillar tube without fin, finned copper capillar tube with the ranges between the fins are $10 \mathrm{~mm}, 20 \mathrm{~mm}$, and $30 \mathrm{~mm}$ and variations of ethanol in premium $0 \%, 5 \%, 10 \%, 15 \%, 20 \%, 25 \%$, and $30 \%$. Experimental method to measure exhaust emissions of $\mathrm{CO}$ and $\mathrm{HC}$ in the engine of Toyota Kijang. The result of this research shows that (1) The lowest carbonmonoxide gas emissions level was foundin the heating of copper pipe with 20 $\mathrm{mm}$ fins distance in the solution of fuel and ethanol 30\% at 0.209 (\% vol). (2) The lowest Hydrocarbon emissions level was found in the heating of pipe with $10 \mathrm{~mm}$ fins distance in the solution of gasoline and ethanol $20 \%$ at 294.33 (ppm vol). (3)The heating of copper pipe with $20 \mathrm{~mm}$ spacing between the fins and the variation of ethanol $30 \%$ is the best result of the entire treatments with CO gas at $0.209(\% \mathrm{vol})$ and HC at 310.00 (ppm vol). (4) The heating in fuel mixture gasoline $75 \%$ and ethanol $25 \%$ through radiator upper tank with gap between fins $10 \mathrm{~mm}$ is the best treatment than from other treatment in testing use with CO t 0,31 (\%vol) dan HC at 340 (ppm vol).
\end{abstract}

Keywords: heating fuel, capillary tube, transversal finned tube, upper tank radiator, CO and HC exhaust emission, ethanol in gasoline

\section{PENDAHULUAN}

Gas buang kendaraan bermotor mengandung unsur-unsur $\mathrm{CO}, \mathrm{NO}_{2}, \mathrm{HC}, \mathrm{C}, \mathrm{H}_{2}$, $\mathrm{CO}_{2}, \mathrm{H}_{2} \mathrm{O}$ dan $\mathrm{N}_{2}$. Karbon Monoksida (CO) adalah gas beracun, tidak berwarna, tidak berbau, dan tidak berasa. Karena sifatnya yang tidak berbau, CO biasanya tercampur dengan gas-gas lain yang berbau, sehingga $\mathrm{CO}$ dapat terhirup dengan tidak sengaja bersamaan dengan gas lain yang berbau. Unsur $\mathrm{CO}$ hasil pembakaran bersifat racun bagi darah manusia saat pernafasan, sebagai akibat berkurangnya oksigen pada jaringan darah. Hidrokarbon (HC) dapat menyebabkan iritasi mata, batuk, rasa mengantuk dan bercak kulit.

Kenaikan harga BBM memunculkan berbagai masalah di setiap bidang, salah satunya adalah masalah di bidang otomotif. Dengan terbatasnya persediaan BBM yang memicu kenaikan harga bahan bakar, langkah positif yang dapat dilakukan adalah dengan melakukan penghematan. Penghematan dapat dilakukan dengan cara penggunaan kendaraan secara bijak, perawatan kendaraan secara berkala, dengan metode penghematan bahan bakar melalui penambahan alat-alat penghemat bahan bakar dan lain sebagainya. Terkait dengan metode penghematan bahan bakar, ada beberapa metode yang dapat dilakukan antara lain meliputi: metode magnet, metode pemanasan (heater), metode gabungan (variasi, pemanasan, dan elektromagnetik), metode cyclone, metode menaikkan kadar oktan bahan bakar, metode penambahan pasokan udara, dan metode kondisi mesin (Sudirman, 2006).

Adanya proses pembakaran yang sempurna akan mempengaruhi konsumsi bahan bakar dan emisi gas buang. Pada mobil yang masih menggunakan karburator, emisi gas buang yang dihasilkan pada putaran idle masih tinggi. Hal tersebut terjadi karena pada saat awal pemakaian mesin banyak memerlukan bahan bakar agar dapat hidup dikarenakan temperatur yang rendah, sehingga pada kondisi ini bahan bakar terbakar tidak sempurna akibatnya emisi gas buang meningkat.

Alternatif lain untuk menaikkan nilai oktan bahan bakar juga bisa dilakukan dengan menambahkan renewable energy yang nilai oktannya tinggi ke dalam bahan bakar, sehingga nilai oktan bahan bakar akan meningkat. 
Senyawa oksigen yang mempunyai keunggulan angka oktan tinggi dan selama ini digunakan untuk adiktif bahan bakar bensin adalah etanol. Etanol merupakan golongan alkohol bersifat fluida inkompresibel yang dapat digunakan sebagai bahan bakar. Bahan bakar etanol dapat dicampurkan dengan bahan bakar bensin untuk pembakaran dalam motor bakar. Bahan bakar bensin dan etanol berdasarkan uji coba oleh BBPT (Badan Pengkajian dan Penerapan Teknologi) Serpong pada perbandingan 9:1 dapat dioperasikan pada teknologi kendaraan bermotor bensin tanpa memodifikasi mesin dan tidak akan merusak komponen mesin (Sulistyo, 2009). Proses pembakaran sempurna akan mempengaruhi gas buang dalam hasil pembakaran.

Pada penelitian ini obyek yang akan digunakan adalah mesin Toyota Kijang 4 silinder karburator. Penelitian ini bertujuan mengetahui pengaruh penambahan etanol dalam bahan bakar bensin pada pemanasan bahan bakar bensin melalui pipa kapiler bersirip transversal di dalam upper tank radiator terhadap emisi gas buang $\mathrm{CO}$ dan HC pada mesin Toyota Kijang.

\section{Metode Penelitian}

\section{Tempat Penelitian}

Penelitian dilaksanakan di Laboratorium Otomotif Program Studi Pendidikan Teknik Mesin, Jurusan Pendidikan Teknik dan Kejuruan, FKIP, Universitas Sebelas Maret yang beralamatkan di Jl. Ahmad Yani no. 200 Pabelan, Surakarta.

\section{Pelaksanaan Eksperimen}

a) Alat Penelitian

Peralatan yang digunakan pada penelitian ini meliputi:

1) Radiator

Radiator yang digunakan adalah radiator yang telah ditambah dengan pipa tembaga dengan variasi jarak antar sirip.

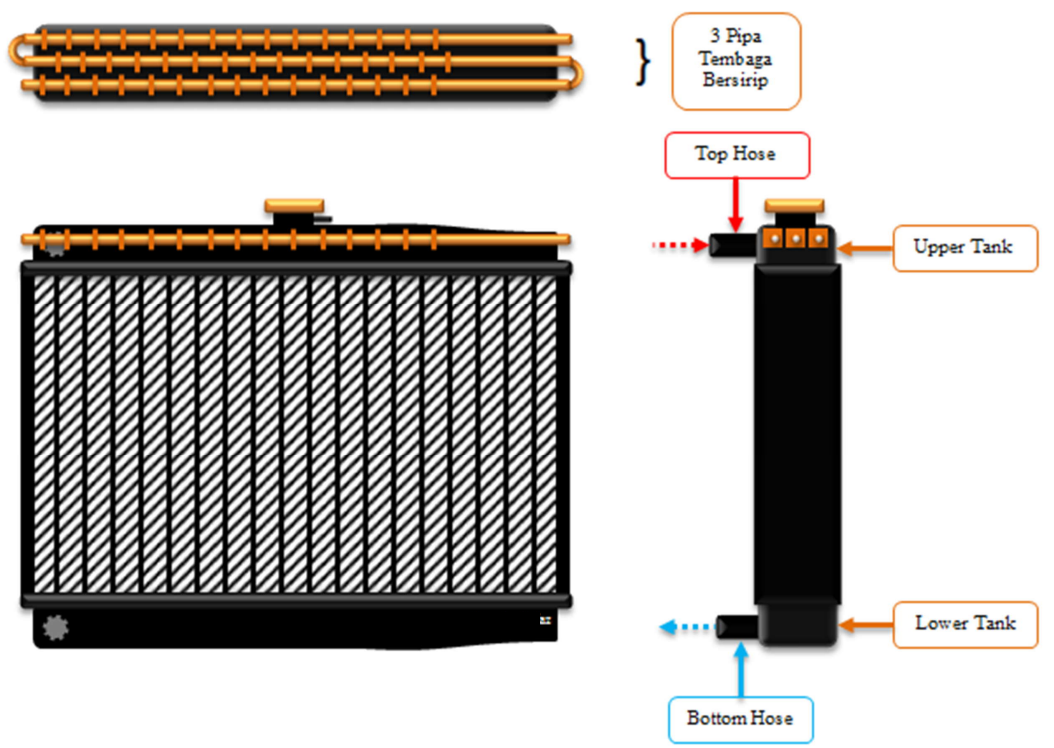

2) Elektroliser Air

Gambar 1. Desain Radiator

3) Gelas Ukur, digunakan untuk mengukur konsumsi bahan bakar bensin

4) Gas analyzer, digunakan untuk mengukur emisi gas buang $\mathrm{CO}$ dan $\mathrm{HC}$

5) Stopwatch, digunakan untuk mengukur waktu yang diperlukan untuk menghabiskan bensin premium

6) Tachometer, digunakan untuk mengukur putaran mesin

7) Thermokopel, digunakan untuk mengukur temperatur air dan bensin

8) Tool Box, digunakan untuk melakukan setting peralatan uji

9) Perlengkapan Observasi :

(a) Lembar pengambilan data

(b) Alat tulis

b) Bahan Penelitian

Bahan yang digunakan pada penelitian ini meliputi:

1) Mesin Uji 
Mesin yang digunakan adalah mesin Toyota Kijang 4 silinder.

2) Bahan Bakar

(a) Bahan bakar bensin jenis premium

(b) Bahan bakar campuran antara premium dengan etanol

c) Desain Eksperimen

1) Skema Aliran Pemanasan Bahan Bakar

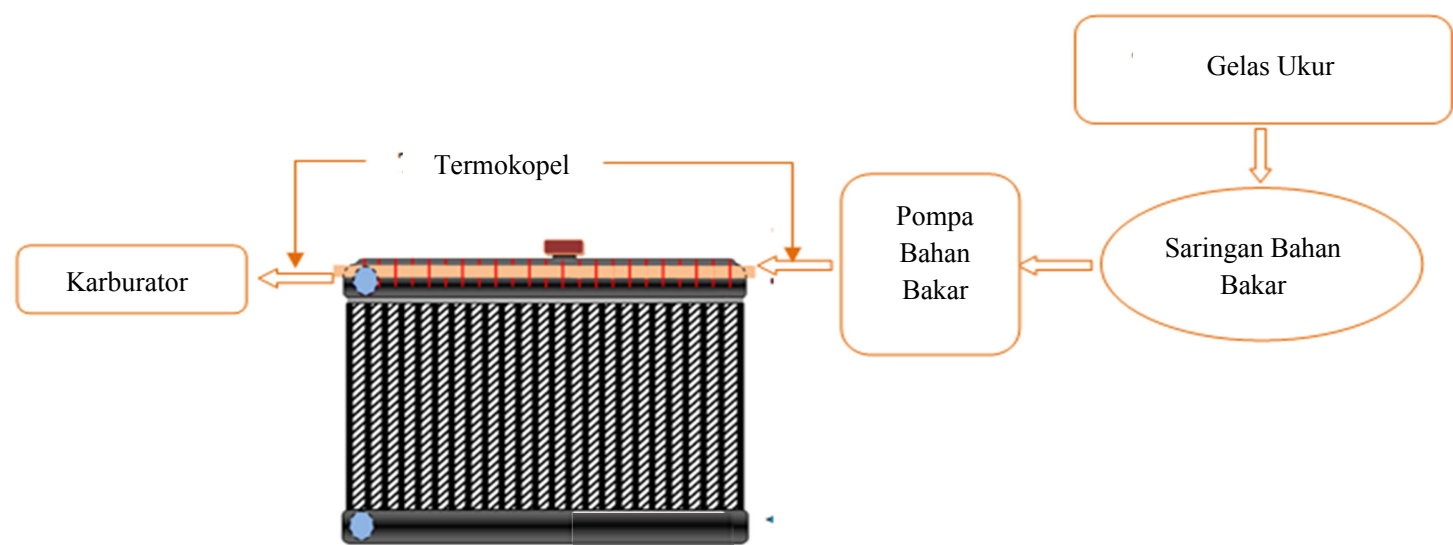

Gambar 2. Aliran Bahan Bakar

2) Tahap Pelaksanaan Eksperimen
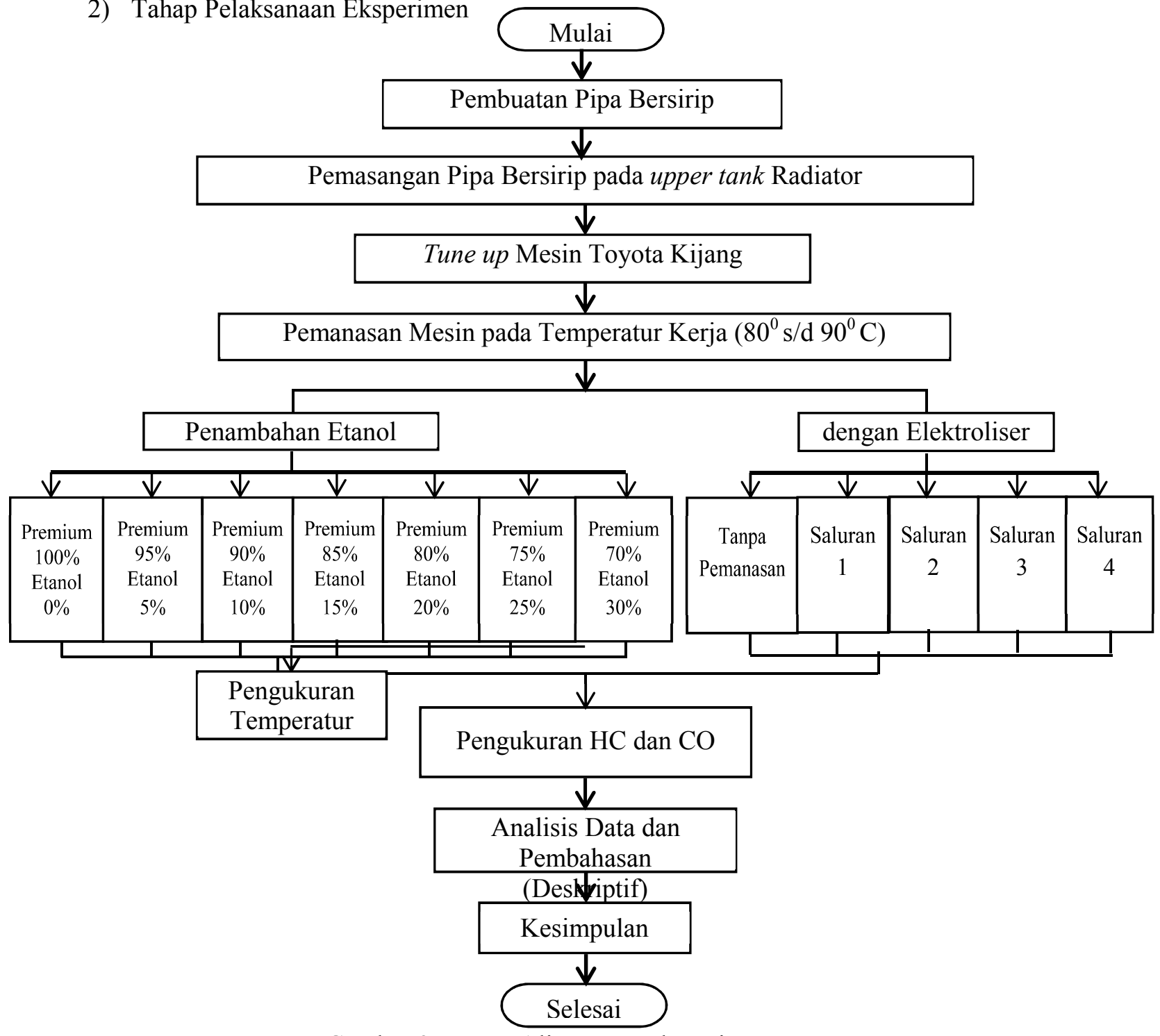

Gambar 3. Bagan Alir Proses Eksperimen 
Keterangan:

Saluran 1 : Penambahan pipa kapiler tanpa sirip

Saluran 2 : Penambahan pipa bersirip dengan jarak antar sirip $10 \mathrm{~mm}$

Saluran 3 : Penambahan pipa bersirip dengan jarak antar sirip $20 \mathrm{~mm}$

Saluran 4 : Penambahan pipa bersirip dengan jarak antar sirip $30 \mathrm{~mm}$

d) Pengambilan Data

Pengambilan data dilakukan

berdasarkan SNI 09-7118.1-2005 untuk pengujian emisi gas buang.

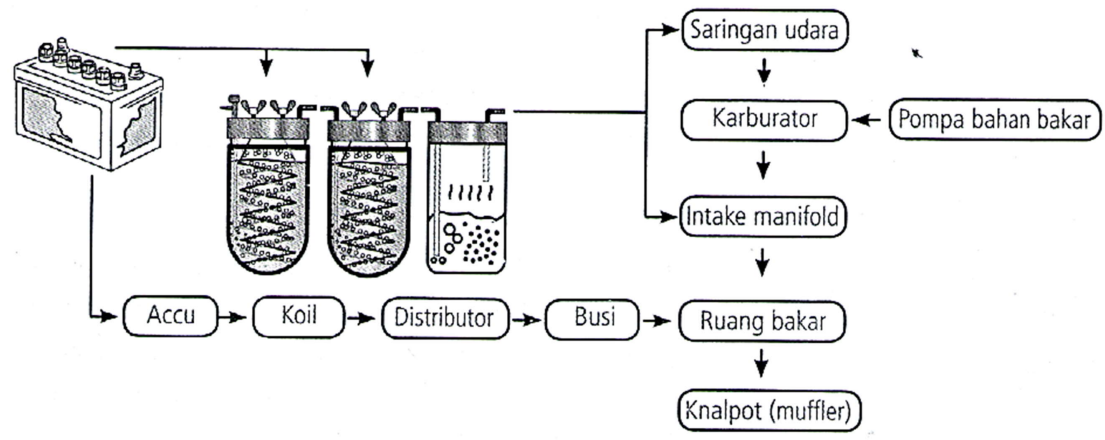

Gambar 4. Skema Instalasi pada Mobil Karburator

\section{HASIL DAN PEMBAHASAN}

Berdasarkan penelitian yang telah dilakukan terhadap emisi gas buang $\mathrm{CO}$ dan HC pada mesin Toyota Kijang menghasilkan data pada tabel 1. berikut :

Tabel 1. Emisi Gas Buang CO dengan Pemanasan Bahan Bakar dengan Pipa Bersirip Persegi

\begin{tabular}{|c|c|c|c|c|c|c|c|}
\hline $\begin{array}{ll}\text { Variasi } \\
\text { Pemanasan } \\
\text { Bahan Bakar }\end{array}$ & $0 \%$ & $5 \%$ & $10 \%$ & $15 \%$ & $20 \%$ & $25 \%$ & $30 \%$ \\
\hline standar & 1,976 & 1,748 & 1,188 & 1,068 & 0,634 & 0,404 & 0,243 \\
\hline Pemanasan pipa tanpa sirip & 1,636 & 1,201 & 1,123 & 0,843 & 0,458 & 0,366 & 0,227 \\
\hline Pemanasan pipa bersirip $30 \mathrm{~mm}$ & 1,612 & 1,175 & 1,074 & 0,754 & 0,397 & 0,304 & 0,211 \\
\hline Pemanasan pipa bersirip $20 \mathrm{~mm}$ & 1,329 & 0,917 & 0,832 & 0,600 & 0,375 & 0,289 & 0,209 \\
\hline Pemanasan pipa bersirip $10 \mathrm{~mm}$ & 1,194 & 0,923 & 0,741 & 0,411 & 0,307 & 0,245 & 0,244 \\
\hline
\end{tabular}

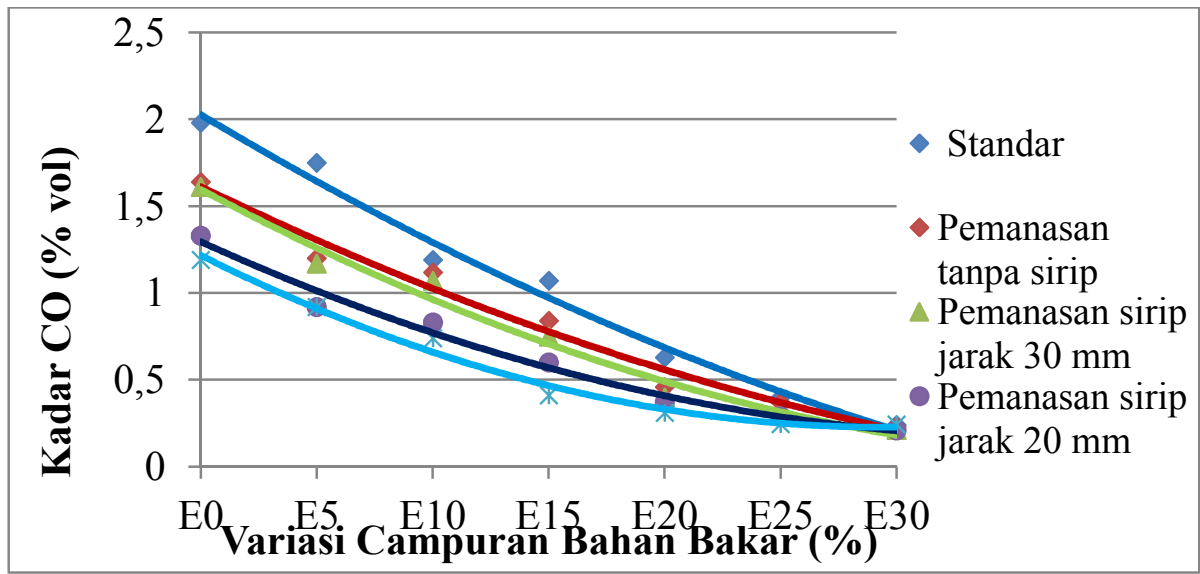

Gambar 5. Hubungan Kadar Karbon Monoksida (CO) dengan Variasi Campuran Bahan Bakar dengan Pemanasan Bahan Bakar dengan Pipa Bersirip Persegi 
Tabel 2. Emisi Gas Buang CO dengan Pemanasan Bahan Bakar Pipa Bersirip Radial

\begin{tabular}{|c|c|c|c|c|c|c|c|}
\hline $\begin{array}{l}\text { Variasi } \\
\text { Pemanasan } \\
\text { Bahan Bakar }\end{array}$ & $0 \%$ & $5 \%$ & $10 \%$ & $15 \%$ & $20 \%$ & $25 \%$ & $30 \%$ \\
\hline standar & 1,98 & 1,75 & 1,19 & 1,07 & 0,63 & 0,4 & 0,24 \\
\hline Pemanasan pipa tanpa sirip & 1,64 & 1,2 & 1,12 & 0,84 & 0,46 & 0,37 & 0,23 \\
\hline Pemanasan pipa bersirip $30 \mathrm{~mm}$ & 1,54 & 1,11 & 1,08 & 0,85 & 0,40 & 0,32 & 0,14 \\
\hline Pemanasan pipa bersirip $20 \mathrm{~mm}$ & 1,50 & 0,95 & 0,92 & 0,55 & 0,32 & 0,3 & 0,49 \\
\hline Pemanasan pipa bersirip $10 \mathrm{~mm}$ & 2,15 & 1,43 & 0,87 & 0,81 & 0,53 & 0,31 & 1,65 \\
\hline
\end{tabular}

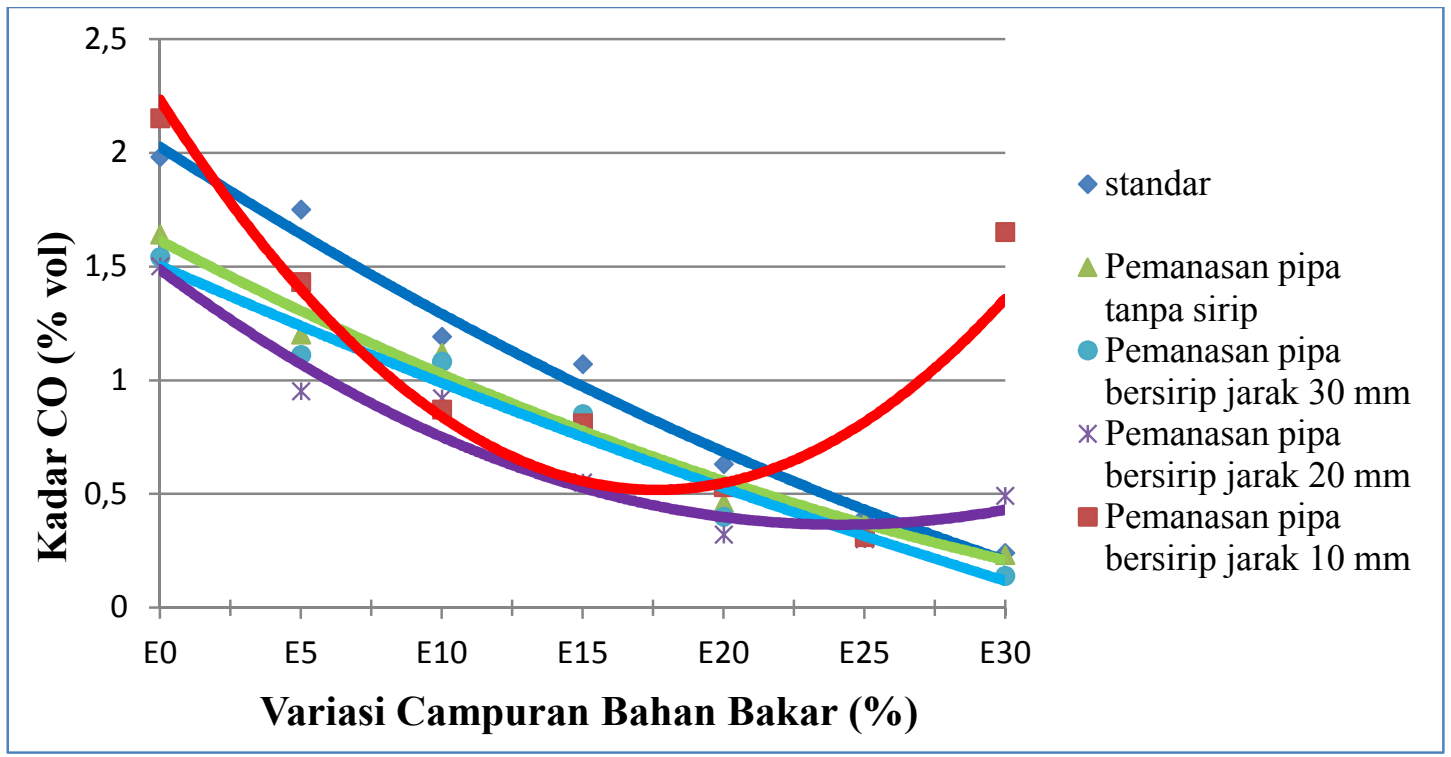

Gambar 6. Hubungan Emisi Gas Buang CO dengan Variasi Campuran Bahan Bakar Premium dan Etanol dengan Pemanasan Bahan Bakar dengan Pipa Bersirip Radial

Tabel 3. Emisi Gas Buang HC dengan Pemanasan Bahan Bakar dengan Pipa Bersirip Persegi

\begin{tabular}{lccccccc}
\hline \begin{tabular}{l} 
Variasi \\
Variasi \\
$\begin{array}{l}\text { Pemanasan } \\
\text { Bahan Bakar }\end{array}$ \\
\hline standar
\end{tabular} & $0 \%$ & $5 \%$ & $10 \%$ & $15 \%$ & $20 \%$ & $25 \%$ & $30 \%$ \\
\hline Pemanasan pipa tanpa sirip & 359,67 & 470,67 & 418,33 & 409,33 & 407,67 & 395,00 & 467,33 \\
\hline Pemanasan pipa bersirip 30 mm & 394,00 & 396,00 & 431,33 & 423,00 & 407,33 & 449,33 & 401,33 \\
\hline Pemanasan pipa bersirip 20 mm & 318,61 & 381,00 & 400,33 & 438,00 & 392,00 & 403,00 & 346,67 \\
\hline Pemanasan pipa bersirip 10 mm & 420,00 & 342,00 & 343,33 & 381,67 & 347,67 & 343,33 & 310,00 \\
\hline
\end{tabular}




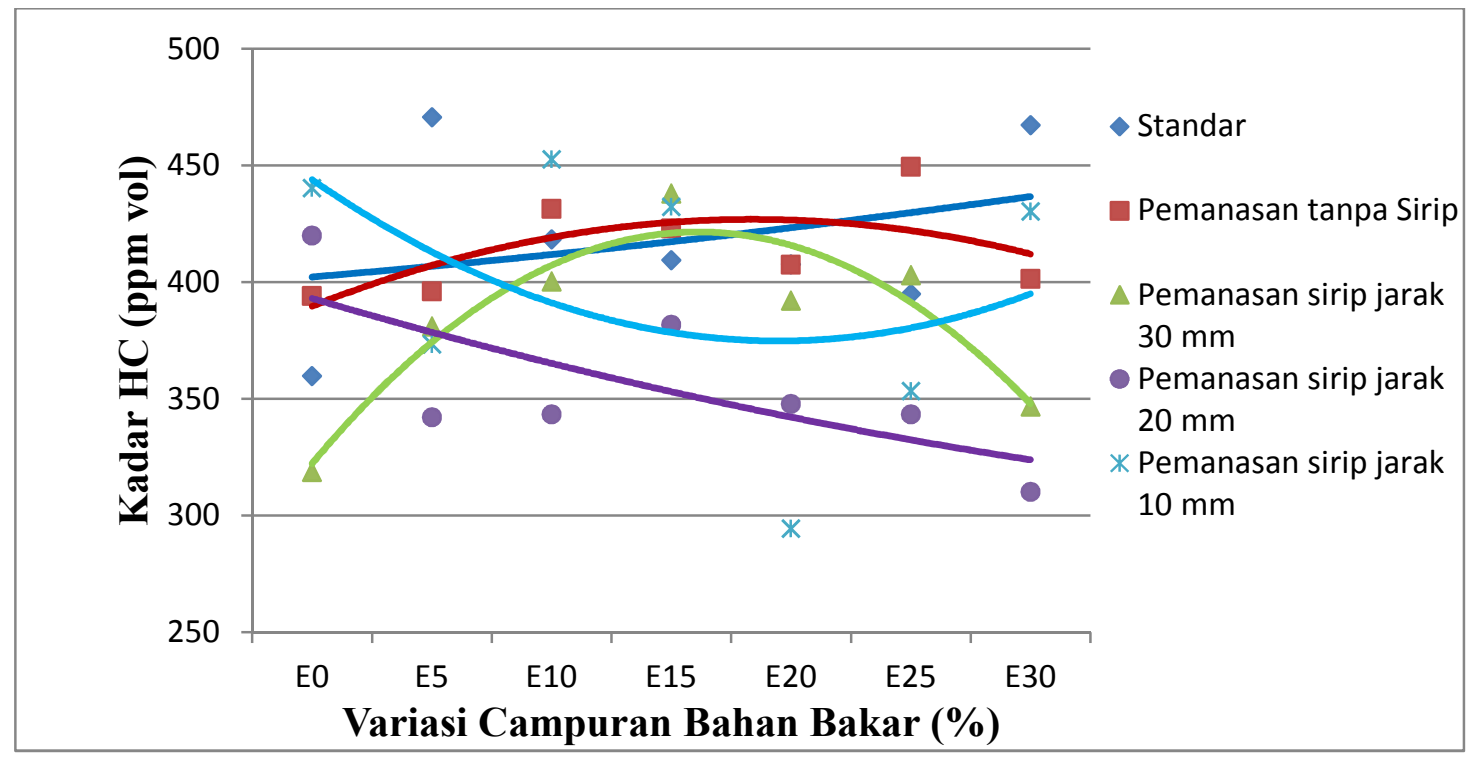

Gambar 7. Hubungan Kadar Hidrokarbon dengan Variasi Campuran Bahan Bakar Premium dan Etanol dengan Pemanasan Bahan Bakar dengan Pipa Bersirip Persegi

Tabel 4. Emisi Gas Buang HC dengan Pemanasan Bahan Bakar dengan Pipa Bersirip Radial

\begin{tabular}{|c|c|c|c|c|c|c|c|}
\hline $\begin{array}{ll}\text { Variasi } \\
\text { Pemanasan } \\
\text { Bahan Bakar }\end{array}$ & $0 \%$ & $5 \%$ & $10 \%$ & $15 \%$ & $20 \%$ & $25 \%$ & $30 \%$ \\
\hline standar & 449,67 & 470,67 & 418,33 & 409,33 & 407,67 & 395 & 467,33 \\
\hline Pemanasan pipa tanpa sirip & 394 & 396 & 431,33 & 423 & 407,33 & 449,33 & 401,33 \\
\hline Pemanasan pipa bersirip $30 \mathrm{~mm}$ & 369,33 & 342 & 374 & 362 & 407 & 453,33 & 400 \\
\hline Pemanasan pipa bersirip $20 \mathrm{~mm}$ & 312,33 & 336,33 & 369 & 434,67 & 373,33 & 333,67 & 416,33 \\
\hline Pemanasan pipa bersirip $10 \mathrm{~mm}$ & 474,33 & 442 & 420 & 411 & 404 & 340 & 774,33 \\
\hline
\end{tabular}

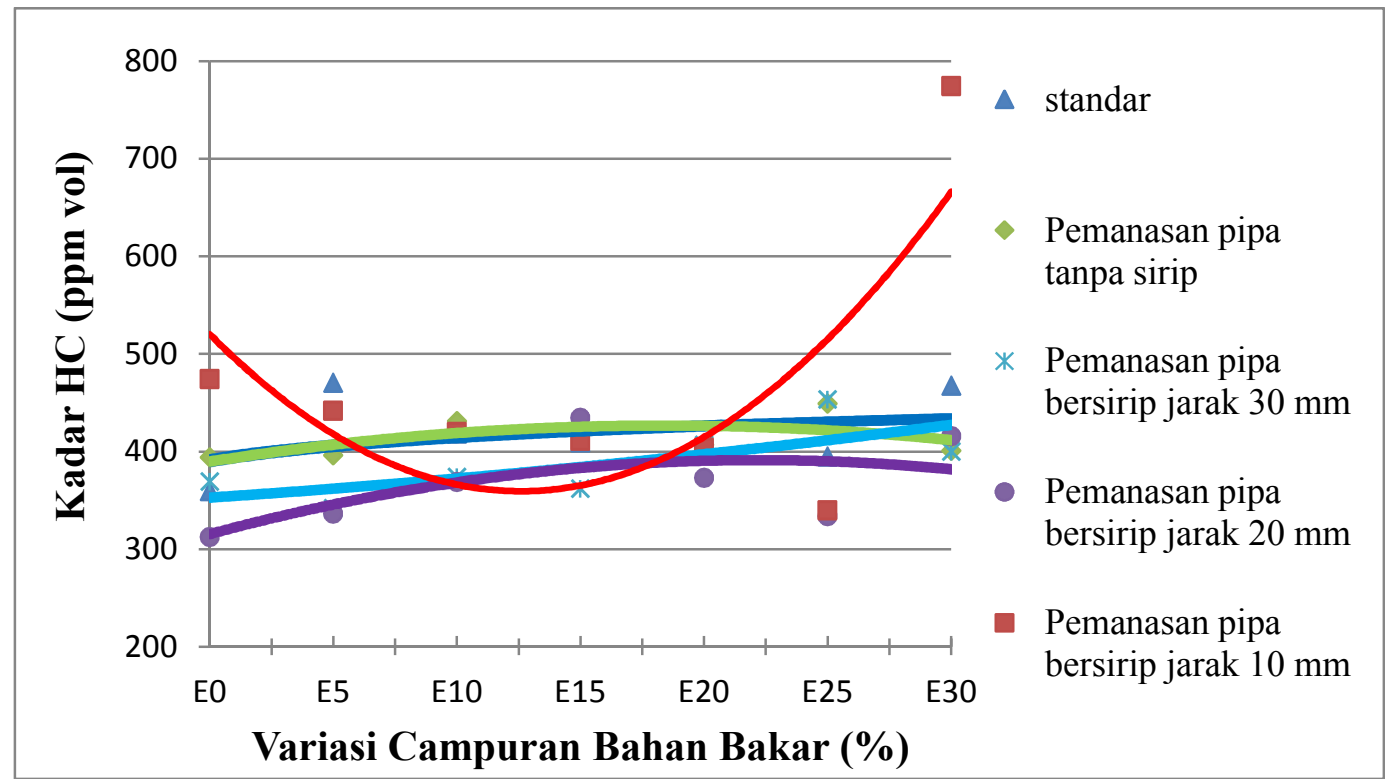

Gambar 8. Hubungan Emisi Gas Buang HC dengan Variasi Campuran Bahan Bakar Premium dan Etanol dengan Pemanasan Bahan Bakar Pipa Bersirip Radial 
A. Pengaruh Penambahan Etanol dalam Premium dan Pemanasan Bahan Bakar Bensin melalui Pipa Kapiler Bersirip Persegi di dalam Upper Tank Radiator terhadap Emisi Gas Buang CO dan HC pada Mesin Toyota Kijang

Dengan membandingkan data tabel 1 dan gambar 5, penurunan kadar emisi terjadi karena titik bakar E0 lebih rendah dibanding dengan titik bakar E30. Penambahan etanol dalam bahan bakar mengakibatkan kenaikan nilai oktan. Nilai oktan yang tinggi menyebabkan bahan bakar lebih sulit terbakar sendiri, sehingga menghasilkan emisi gas buang yang lebih ramah lingkungan.

Dari data pengujian, didapat bahwa kadar $\mathrm{CO}$ terbaik terdapat pemanasan dengan jarak antar sirip $20 \mathrm{~mm}$ dengan variasi campuran bahan bakar premium 70\% dan etanol 30\% dengan nilai sebesar $0,209(\%$ vol) pada suhu bahan bakar awal sebelum masuk ke dalam pipa pemanas sebesar $49,3{ }^{\circ} \mathrm{C}$ dan keluar dari pipa pemanas $66,3{ }^{\circ} \mathrm{C}$. Suhu air pendingin awal sebelum masuk ke dalam radiator sebesar $80,8{ }^{\circ} \mathrm{C}$ dan keluar dari radiator 59,7 ${ }^{\circ} \mathrm{C}$. Suhu bahan bakar masuk setelah dilakukan pengujian sebesar $49,3{ }^{\circ} \mathrm{C}$, dan suhu keluar sebesar $68,0{ }^{\circ} \mathrm{C}$. Suhu air pendingin sebelum masuk ke dalam radiator setelah pengujian sebesar $80,4{ }^{\circ} \mathrm{C}$ dan keluar dari radiator setelah pengujian sebesar 73,3 ${ }^{\circ} \mathrm{C}$.

Dengan membandingkan data pada tabel 3 dan gambar 7 di atas, terjadi penurunan kadar HC dalam emisi gas buang sebesar 158,34 (ppm vol). Pada campuran bahan bakar E10 adanya kenaikan kadar HC yang sangat signifikan hal ini disebabkan oleh karakteristik mesin yang seharian digunakan untuk pengujian. Pada campuran bahan bakar E20, kadar HC menurun. Menurunnya kadar $\mathrm{HC}$ ini disebabkan karena mesin yang sering digunakan. Akibat dari penggunaan mesin yang sering yaitu panas mesin lebih tinggi. Panas mesin inilah yang menyebabkan bahan bakar yang masuk ke dalam ruang bakar mempunyai suhu yang lebih tinggi, sehingga bahan bakar lebih mudah dibakar.

Dari seluruh data yang didapat, kadar HC terbaik terdapat pada pemanasan bahan bakar dengan variasi jarak antar sirip $10 \mathrm{~mm}$ dengan variasi campuran bahan bakar E20 dengan nilai sebesar 294,33 (ppm vol) pada suhu bahan bakar awal sebelum masuk ke
Karbon Monoksida (CO) dari campuran bahan bakar E0 ke E30 sebesar 0,950 (\% vol). Pada campuran bahan bakar E30 bahan bakar bisa terbakar secara sempurna. Pada E0 pembakaran yang terjadi tidak sempurna. Pembakaran yang tidak sempurna pada E0

dalam pipa pemanas sebesar $50,2{ }^{\circ} \mathrm{C}$ dan keluar dari pipa pemanas $68,5{ }^{\circ} \mathrm{C}$. Suhu air pendingin awal sebelum masuk ke dalam radiator sebesar $80,2{ }^{\circ} \mathrm{C}$ dan keluar dari radiator $58,7{ }^{\circ} \mathrm{C}$. Suhu bahan bakar masuk setelah dilakukan pengujian sebesar $55,7{ }^{\circ} \mathrm{C}$ dan suhu keluar sebesar $70,8{ }^{\circ} \mathrm{C}$. Suhu air pendingin sebelum masuk ke dalam radiator setelah pengujian sebesar $82,1{ }^{\circ} \mathrm{C}$ dan keluar dari radiator setelah pengujian sebesar 76,3 ${ }^{\circ} \mathrm{C}$.

Dengan membandingkan seluruh data yang didapat, pengujian dengan pemanasan pipa tembaga dengan jarak antar sirip $20 \mathrm{~mm}$ dengan variasi bahan bakar 30\% mempunyai kadar $\mathrm{CO}$ yang paling rendah dan kadar $\mathrm{HC}$ lebih tinggi daripada pemanasan dengan pipa tembaga dengan jarak antar sirip $10 \mathrm{~mm}$ pada variasi bahan bakar $20 \%$. Melihat bahwa resiko di antara kedua gas terhadap manusia dan lingkungan, maka pemanasan pipa bersirip persegi dengan jarak antar sirip 20 $\mathrm{mm}$ dan variasi bahan bakar $30 \%$ merupakan pengujian dengan perlakuan dengan hasil yang paling baik dibanding dengan perlakuan lain pada pengujian ini.

B. Pengaruh Penambahan Etanol dalam Premium dan Pemanasan Bahan Bakar Bensin melalui Pipa Kapiler Bersirip Radial di dalam Upper Tank Radiator terhadap Emisi Gas Buang CO dan HC pada Mesin Toyota Kijang

Panas yang diserap oleh pemanasan menggunakan tiga pipa tembaga, membuat bahan bakar yang mempunyai rantai karbon penyusun bahan bakar dari molekul kurang baik (rantai karbon lurus) menjadi rantai karbon bercabang lebih banyak. Semakin banyak jumlah sirip pada pipa tembaga membuat suhu bahan bahan bakar meningkat. Semakin suhu bahan bakar meningkat membuat cabang rantai karbon pada bahan bakar semakin banyak, sehingga premium lebih mudah bercampur dengan udara yang masuk ke dalam silinder. Homogenitas campuran bahan bakar dan udara akan lebih baik. Homogenitas campuran yang semakin 
baik membuat sistem pembakaran yang semakin baik, sehingga gas buang yang dihasilkan juga semakin baik.

Elektroliser Air menghasilkan gas $\mathrm{HHO}$ (Hidrogen-Hidrogen-Oksigen) hasil dari elektrolisis air. Gas HHO terdiri atas 2 hidrogen dan 1 oksigen. Penambahan gas HHO ini akan berdampak pada proses pembakaran mesin kendaraan bermotor. Hidrogen gas yang mudah terbakar dan oksigen gas untuk membantu pembakaran, sehingga akan terjadi pembakaran yang lebih baik dan menghasilkan gas $\mathrm{CO}$ yang lebih sedikit.

Penurunan emisi gas buang CO pada setiap variasi campuran bahan bakar premium dan etanol, menunjukkan bahwa di dalam bahan bakar yang digunakan terjadi perubahan kandungan unsur senyawa premium dan etanol. Atom oksigen yang terkandung dalam etanol akan bercampur dengan bahan bakar, sehingga kadar oksigen pada campuran bahan bakar dan udara akan meningkat. Proses pembakaran yang banyak mengandung oksigen. Oksigen yang ada akan bereaksi dengan gas buang, serta menurunkan emisi gas buang $\mathrm{CO}$, dengan demikian semakin banyak kandungan etanol semakin rendah emisi gas buang $\mathrm{CO}$.

Variasi bahan bakar premium murni ke campuran bahan bakar premium dan etanol terjadi perubahan yang fluktuatif. Hal ini disebabkan oleh karakteristik mesin kendaraan dan karateristik bahan bakar yang digunakan. Premium murni sampai campuran etanol 25\% mengalami penurunan gas buang HC. Hal ini titik bakar premium lebih rendah daripada campuran etanol $25 \%$. Campuran etanol $25 \%$ sampai campuran $30 \%$ terjadi kenaikkan gas buang HC. Hal ini disebabkan kadar oktan yang meningkat.

4. $0,31(\% \mathrm{vol})$ dan $\mathrm{HC}$ sebesar 340 (ppm vol).
Dengan membandingkan seluruh data yang didapat, bahwa pengujian dengan pipa bersirip radial dengan jarak antar sirip $30 \mathrm{~mm}$ dengan bahan bakar campuran etanol 30\% mempunyai kadar $\mathrm{CO}$ yang rendah. Akan tetapi untuk kadar HC lebih tinggi daripada pemanasan dengan pipa tembaga jarak antar sirip $20 \mathrm{~mm}$. Pengujian dengan pipa tembaga jarak antar sirip $20 \mathrm{~mm}$ dengan bahan bakar Premium 100\% mempunyai kadar HC rendah. Akan tetapi untuk kadar CO lebih tinggi daripada pemanasan dengan pipa tembaga jarak antar sirip $30 \mathrm{~mm}$. Melihat resiko di antara kedua gas terhadap lingkungan, maka pemanasan pipa bersirip radial dengan jarak $10 \mathrm{~mm}$ dengan bahan bakar campuran etanol 25\% merupakan perlakuan dengan hasil yang lebih baik dibanding perlakuan lain pada pengujian ini.

\section{KESIMPULAN}

Berdasarkan data dan hasil uji coba pada penelitian pengaruh pemanasan bahan bakar pada mobil Toyota Kijang dapat disimpulkan bahwa:

1. Variasi pemanasan bahan bakar melalui pipa bersirip transversal di dalam upper tank radiator dan variasi penambahan etanol pada bahan bakar bensin mempengaruhi emisi gas buang $\mathrm{CO}$ dan $\mathrm{HC}$ pada Toyota Kijang.

2. Pemanasan pipa bersirip persegi dengan jarak antar sirip $20 \mathrm{~mm}$ dan campuran bahan bakar premium $70 \%$ dan etanol $30 \%$ merupakan hasil terbaik dari seluruh perlakuan dengan gas CO sebesar 0,209 (\%vol) dan HC sebesar 310,00 (ppm vol).

3. Kadar emisi gas buang $\mathrm{CO}$ dan $\mathrm{HC}$ yang terbaik terdapat pada pemanasan pipa bersirip radial di dalam upper tank radiator dengan jarak antar sirip $10 \mathrm{~mm}$ menggunakan campuran bahan bakar premium $75 \%$ dan etanol 25\% dengan kadar CO sebesar

\section{DAFTAR PUSTAKA}

As'adi, M. (2010). Uji Pemasangan Brown Gas terhadap Performa Motor Bensin Empat Langkah. Jakarta : Koleksi Perpustakaan UPN Veteran

Daryanto. (2006). Teknik Merawat AutoMobil Lengkap. Bandung : Yrama Widya

Firdaus, M.Y. (2012). Pembakaran. Diperoleh 12 Mei 2012 dari http://muhammadyusuffirdaus.wordpress.com/2012/01/22/pembakaran/

Global Renewable Energy \& Power Inc. (GREPI). 2011. Renewable Hydrogen. Diperoleh 07 Juni 2012 dari http://www.grepinc.com/technology/renewable-hydrogen

Majid. (2011). Racun Gas Karbon Monoksida. Diperoleh 18 Juni 2012 dari http://xa.yimg.com/kq/groups/9413146/259254791/name/RacunGasKarbonMonoksida.pdf 
Mandiri, Arisco. (2011). Radiator. Diperoleh $25 \quad$ Mei 2012 dari http://indonetwork.co.id/ariscomandiri/1655473/radiator-core-radiator.htm

Nurhidayat, M.A. (2007). Sistem Bahan Bakar Bensin dan Injeksi Diesel. Bandung: CV.Yrama Widya

Peha. 2011. Kiat Merawat Radiator Mobil. Diperoleh 27 Mei 2012 dari http://internetaja.blogspot.com/2011/03/kiat-merawat-radiator-mobil.html

Pusat Pelatihan PT. Indomobil Suzuki International. (2003). Text Book Training Mekanik-D : Basic Automotive. Jakarta: PT. Indomobil Suzuki International.

Suratman, M. (2005). Pemeliharaan / Servis Sistem Bahan Bakar Bensin dan Diesel SMK. Bandung: Armico

Toyota Astra Motor. Toyota Materi Pembelajaran Engine Group Step 2. Jakarta: P.T. Toyota Astra Motor

Ulet. (2010). Hidrokarbon (HC). Diperoleh 26 April 2012 dari http://ultrawomen.wordpress.com/2010/02/15/hidrokarbon-hc/

Yovanovich. (2009). Radial Fin Profile. Diperoleh 5 Juni 2012 dari http://commonemitter.wordpress.com/category/heat-transfer/ 